\title{
Stoning Law and Human Rights
}

\author{
Abdullah $^{1}$, Muntasir $^{2}$, Safrizal $^{3}$ \\ 1,3Institut Agama Islam (IAI) Al-Aziziyah, Aceh, Indonesia \\ 2Universitas Malikussaleh, Aceh, Indonesia \\ Email: abdullah@iaialaziziyah.ac.i
}

Abstract: The law contained in Islam can provide values and an essential sense of justice for all Muslim and non-Muslim human beings. One of the laws in Islam is stoning. Adultery is an act that has been forbidden by Allah and is included in a big and very heinous sin. The application of the law of stoning was first applied in Islam before the conquest of Mecca (fathul Mecca), and before the revelation of Surah An-Nur verse 2 regarding vols (whips), Most scholars agree that for adulterers who are muhsan the punishment is death by being stoned with stones or the like. However, there is no reference that states that the type of stoning law violates human rights or does not violate human rights, but the highlight here is the stoning (death) punishment. Whether the death penalty violates human rights or not, this becomes a controversy between one party and another who has a different perspective, the concept of human rights in Islam is different from the concept of human rights in the perspective of western countries.

Keywords: stoning law; human rights

\section{Introduction}

Allah SWT has bestowed upon mankind His greatest favor in this world, namely alIslam. A religion that is rahmatan lil almiin (grace to the whole world). The laws contained in Islam are so beautiful and provide value and an essential sense of justice for all Muslims and non-Muslims alike. Not a single soul is harmed by Islam. Laws, rules, values, and ethics in Islam are the most perfect.

One of the laws in Islam is the law of stoning, where the law of stoning in the history of the application of Islamic law is projected as a form of punishment for the perpetrators of the crime of adultery for those who have been married (muhsan). Meanwhile, for unmarried adulterers (ghairu muhsan), the punishment is one hundred lashes. The provisions for stoning and whipping are a form of jarimah hudud, namely a criminal act whose form and limits have been determined in the Qur'an and Hadith. In addition to the punishments that have been clearly defined in the Qur'an and al-Hadith, Islam also applies the form of jarimah ta'zir, namely criminal acts whose forms and legal threats are not contained in the Qur'an and alHadith but determined by the authorities as a lesson for the perpetrators.

However, in the application of the stoning law, there are many conflicts made by various parties, especially by human rights activists. The basis of this conflict is that stoning is a form of punishment that is considered a cruel, primitive, and inhuman form or type of punishment, and is no longer appropriate to be applied in modern times, namely carrying out the death penalty by throwing stones.

Moving on from this thought the author wants to learn about stoning law and human rights. So in this short paper, the author tries to analyze or focus on understanding, history, punishment for mukhsan adulterers and stoning from a human rights perspective. 


\section{Review of Literatures}

\subsection{Definition of Stoning}

Before we define stoning, it is necessary to first define adultery. Adultery is the act of sexual intercourse by inserting the male genitalia into the female genitalia outside the marriage contract, whether married (mukhsan) or unmarried (ghairu mukhsan) (Jalaluddin al-Mahally). The law of stoning is a death law for those who have been married or have been married by stoning (Ibnu Qasim al-Ghazhy). This law is not carried out except in the case of a very despicable act and a grave sin. This punishment is only carried out if the recipient of the law is really proven very convincingly in the presence of four fair male witnesses or with the confession of the perpetrator who asked the judge to law him. Meanwhile, for adulterers who have never been married (ghiru mukhsan), they are subject to lashes of 100 (one hundred) times (Ibnu Qasim al-Ghazhy).

This act (adultery) is an act that has been forbidden by Allah and is included in the act of a great and very heinous sin, because the negative effects of this adultery can destroy the benefit of life in maintain lineage (descendants), and also maintain the genitals and honor, besides that it can also cause various venereal diseases (Ali Ahmat Al-Jarjawi, 2006).

So if you look at the consequences of these actions, it is very reasonable and appropriate that Islam provides severe sanctions for adulterers, especially those who have been/have been married, namely in the form of stoning. Meanwhile, those who were not married were punished with whipping and exiled.

\subsection{Stoning Before Islam}

The punishment of stoning has actually existed since the prophets and apostles before the prophet Muhammad SAW. Such punishment also applies officially in Jewish and Christian Shari'a.The implementation of stoning for adulterers is not only found in Islamic teachings or as the first to apply such harsh punishments. However, punishments aimed at preserving the morality of the people were also applied by other divine religions before the advent of Islam (Khairul Fahmi, 2009).

Furthermore, in the Torah, the provisions of the law of stoning (stoning to death) as a form of punishment for certain types of crimes, and adultery is one of the types of crimes that are stoned. The teachings in the book explain that there are several types of punishments applied to perpetrators of sexual crimes, such as being cut off from life, lips and bitten by dogs to death (Hasbullah, 2019).

If we look at the original sources of the sacred law of Judaism, Christianity and Hinduism, it clearly states that adultery is a heinous crime which is strongly opposed and will be severely punished which results in the death of the adulterer, both male and female. Based on this view, it is not unreasonable if Jews, Christians, Judaism and Hindus allege that only the legal system in Islam applies this punishment to those who commit adultery. After considering some of the sources above, it is clear that this kind of punishment by stoning has existed long before the Prophet Muhammad was sent to convey the teachings of Islam to the surface of this earth. 


\subsection{The Punishment of Stoning During the Development of Islam}

The application of the law of stoning was first applied in Islam before the conquest of Mecca (fathul Mecca), and before the revelation of Surah An-Nur verse 2 regarding vols (whips), which is based on the history in Sunan Ibn Majah that a man named Ma'iz complained and confessed to the Messenger of Allah that he had committed adultery. But the Apostle ignored his complaint and looked away from it, until he came and repeated his confession to the Apostle up to four times, then the Apostle told him to look for 4 witnesses, after bringing 4 (four) witnesses, the Apostle asked "are you crazy?" answered "no". Then the Apostle asked again, "have you ever been married?" answered "yes", "do you know what adultery is?" he replied "know O Messenger of Allah" then, "take this person and stone him". When the death law by stoning was carried out, suddenly Maiz felt pain and ran away, some of the friends chased and stoned her again until she died, after that they went to the Apostle and reported the incident, but the Apostle said "why don't you just let Maiz run just?" (HR. Muslim) (Maktabah Syamilah).

In another hadith the Prophet also said, From Ibn Mas'ud ra, he said, Rasulullah sallallaahu 'alaihi wasallam said:

"It is not lawful for the blood of a Muslim to testify that there is no god but Allah and that I (the Messenger of Allah) is the Messenger of Allah except for three reasons, namely, adultery, killing another person (intentionally), and leaving his religion apart from his congregation." (Narrated by Bukhari and Muslim) (Maktabah Syamilah).

While the determination of the caning law (volume) of adulterers who are ghairu muhsan is based on the verse of the Qur'an which means:

"The woman who commits adultery and the man who commits adultery, you must bind each of them a hundred lashes, and do not be influenced by compassion for both of them in carrying out Allah's religious law, if it is true that you believe in Allah and the hereafter, and let the punishment of the lashing be witnessed by a group of believers" (Surah An-Nur: 2) (Ministry of Religion of the Republic of Indonesia, 2004).

The majority of scholars agree that the adulteress of muhshan is punished by stoning, which is being stoned to death. The proof is the hadith of the Prophet Muhammad, namely:

"From Masruq from Abdillah ra. said that the Messenger of Allah said, "The blood of a Muslim is not lawful except for one of three things: the person who commits adultery, the person who kills and the person who apostates and leaves the congregation."

In addition, in fact this stoning punishment was ordered in the Quran, butthe pronunciation is then sanctified, but the law still applies (Ibrahim al-Bajuri ). It was the caliph Umar bin Al-Khattab who stated that in the past there was a verse of the Qur'an that was revealed and its contents were:

"Those who are married, men and women, if they commit adultery, then stone them..."

So the effect of the wording is, there are opinions of some scholars who reject the stoning punishment on the grounds that it is not contained in the Qur'an, only in the hadith. The Prophet Muhammad (PBUH) gave it to the Jews. Another reason is that in the Qur'an it is determined that the punishment for adultery committed by slaves is half that of a free person. However, the death penalty cannot be divided in two (Hasanuddin Yusuf). 


\section{Discussion}

\subsection{The Punishment of Stoning for a Muhshan Adulterer}

In Islam, a legally valid marriage aims in addition to fostering a household, it is also a place to have legal sexual relations and get a reward. With marriage, men and women can channel their sexual urges naturally and are protected by law, and are moral. On the other hand, if sexual relations are carried out outside the marriage bond, then the act is a violation of the law, a major sin, destroys morality and ethics and gets a very heavy penalty.

Punishment for adulterers who have been married, as described above that the argument for the punishment is based on the hadith of the Prophet, namely the death penalty by stoning (stoning). The Prophet Muhammad has stated in his hadith regarding muhsan adulterers that the punishment is stoning for both men and women and 100 (one hundred) lashes for unmarried adulterers. The application of this punishment has also been practiced by the caliphs in the history of their leadership. However, regarding the law of stoning, legal experts (fuqaha) differ in interpreting the determination of the proposition and the process of implementing the law.

Most scholars agree that for muhsan adulterers, the punishment is stoning, namely the death penalty by being stoned or the like. However, the Khawarij reject the stipulation of stoning for adulterers, because according to the Khawarij group, the hadith that is used as a proof in determining the punishment is not a mutawatir hadith, but a Sunday hadith narrated by only one friend, namely Ubadah ibn Shamit. They further state that the punishment for the jarimah (criminal act) of adultery, whether muhshan (never married) or ghairu Muhshan (never married) is a hundred times lashes based on the word of Allah in Surah An-Nur verse 2 mentioned above (Abd al-Al-Qadir Audah).

Al-Allama Badruddin Al-Aini stated that the Prophet continued to prescribe the punishment of stoning even after the revelation of Surah An-Nur verse 2 regarding the volume for adulterers. Likewise, the Imams of the Sunni schools of thought and the majority of scholars state that the punishment for adulterers of muhshan is stoning, both for men and for women. This is as the hadith narrated byAisha, the Messenger of Allah said:

"It is not lawful for the blood of a Muslim to testify that there is no god but Allah and that I am the Messenger of Allah except for three reasons: a married person (muhshan) commits adultery, kills another person (intentionally), and leave his religion (apostasy). (History of Bukhari and Muslim) (Maktabah Syamilah).

In the history of the death penalty by stoning at the time of the Prophet, Ma'iz bin Malik had complained to the Prophet that he had committed adultery, but his confession was rejected by the Prophet until he repeated it 3 (three) times. Finally, when Ma'iz did not withdraw his complaint and he asked to be punished, the Messenger of Allah asked his companions to punish him by stoning.

As explained above, stoning was also practiced when a married Ghamidiyah woman came and confessed to the Prophet that she had committed adultery. He asked the Messenger of Allah to punish him to be free from this great sin. However, the law was postponed until the woman gave birth. After giving birth she came again to the Apostle to ask that she be punished. But the Apostle refused until he raised his son. And after that a new law of stoning was carried out on the woman (Ibrahim al-Bajuri). 
So the determination of the punishment of stoning for adulterers is based on the hadith and the sunnah of the Prophet which the punishment is for those who are muhshan, namely for those who are married, and this is an absolute requirement in determining the punishment of stoning. The conditions for a person to be categorized as muhshan (Khairul Fahmi) are as follows:

a. Coitus in a legal marriage contract

b. Balig and Intellect

c. The existence of perfect conditions for both parties at the time of intercourse.

d. Islam

Imam Malik does not require baliq and reason for both parties, but it is sufficient for only one party. Thus according to Imam Malik, a man is considered a muhshan if he has fulfilled the conditions of ihshan, and a woman is able to have intercourse even though she is underage or insane. Similarly, women can become muhshan with the fulfillment of the conditions of ihshan and the maturity of the husband who has sex with her even though he is crazy.

Among the Shafi'i school, there are two opinions on this matter. The first opinion is the same as the opinion of Imam Abu Hanifah, namely that both people who have intercourse must be both mature and reasonable. While the second opinion is the same as the opinion of Imam Malik, namely that it is not necessary for both of them to be mature and intelligent, but only one of them is sufficient (Abd Al-Qadir Audah).

Imam Abu Hanifah and Imam Malik made Islam one of the conditions for Ihshan (Muhshan). The reason is the hadith of the Prophet Muhammad when he was asked for his opinion by Hudzaifah about marriage with a Kitabiyah woman, he saidsaid as follows: "Leave her, because she (the woman Kitabiyah) does not cause you to become ihshan".

However, Imam Syafii and Imam Ahmad did not make Islam one of the conditions for ihshan. Their reasoning was that the Messenger of Allah, peace be upon him, had carried out the stoning of two Jews who had committed adultery and neither of them had converted to Islam. Had Islam been a condition of ihshan, the Messenger of Allah would not have stoned him. Besides that, indeed all religions generally prohibit adultery, as is prohibited by Islam. This opinion is supported by Imam Abu Yusuf, the Zahiriyah Group, and one of the opinions of the Zaidiyah Shi'ite school. Thus, if a Muslim man who marries a non-Muslim woman commits adultery, according to Imam Abu Hanifah, he is not stoned, because he is not considered muhshan. Meanwhile, according to Imam Malik, Imam Syafii, Imam Ahmad, Zahiriyah, and some Zaidiyah Shiites, he was lawd to stoning, because marriage and intercourse with non-Muslim women made him a muhshan (Khairul Fahmi).

\subsection{Stoning in Human Rights Perspective}

In determining the position of stoning from a human rights perspective, the nature of stoning itself will first be explained. The law of stoning is imposed on adulterers who have been married (muhsan), by stoning to death. The provisions of this stoning punishment are based on the provisions of the hadith of the Prophet Muhammad, not based on just one hadith but there are many hadiths, both in the form of qauli hadith (words / words) and fi'li hadith (practice).

In a hadith narrated by Muslim and others it is stated that "when he (Ma'iz) was stoned, then he felt a stone being thrown. He groaned (pain), then he got out and ran. So Abdullah bin Unais followed him. While his other friends were tired. Then Abdullah took the camel's calf bone and threw it so that he killed it. Then he came to the Messenger of Allah, 
and told him. So he said, "Don't you let him, maybe he repents, then Allah accepts his repentance." (Narrated by Muslim).

From the verses of the Qur'an and the hadith, it can be understood that the punishment of stoning is not as cruel as imagined and accused by non-Muslims (Western orientalists) who are said to be against human rights. From the two texts it can be understood that the stoning law does not have to be completed in certain circumstances (the perpetrator fled) for example. The words of the Prophet above, seem to show resentment towards his friend (Abdullah bin Unais) who chased and killed people who ran away from the execution of stoning (Ma'iz).

In another hadith, the Prophet SAW. said, "The pen is lifted from the community by accident and forgetfulness, and because it is forced" (Narrated by Baihaqi and Ibn Majah from Ibn Abbas). What it means is that you are not burdened by the law in these three cases. For example, adultery because it is forced by others with threats, then it is not subject to punishment for it, as well as other crimes that have elements of coercion and threats from other parties.

In another hadith "Avoid hudud from the Muslims as much as you can, if there is a way out, then make it easy for him. Verily the Imam (leader) who is wrong in his forgiveness is better than the Imam who is wrong in imposing sanctions. "Leave hudud because (there is) doubt" (HR. Baihaqi).

The arguments of the hadith above are sufficient to be a benchmark that the hudud, including the stoning law in it, is not easy to just apply and impose on someone who is considered guilty, but through a mechanism that is quite strict and not haphazard. As has been explained in the discussion of evidence, that the purpose of criminal law in Islamic law is as a lesson and prevention, even though someone has actually been guilty (committed adultery), but if the evidence is not fulfilled, then whipping or stoning cannot be carried out. Therefore, everything is carried out or not punishment in Islam depends on the evidence (the proving process).

From some existing literature, there has not been found a punishment that definitely violates human rights or does not violate human rights, but the highlight here is stoning (death). Whether the death penalty violates human rights or not, this becomes a controversy between one party and another with different perspectives.

There are two versions of the protection of human rights, human rights from an Islamic perspective and human rights from a western perspective. Human rights in Islam have existed long before the human rights in the West were born. The two versions of human rights are very contradictory, especially in matters of criminal law. Criminal law in Islam (hudud) comes from God, in which it aims to protect human rights (Ahkamaul Khamsah: protect religion, soul, mind, property, lineage/honor), which according to the Western perspective is contrary to the human rights they profess. While the criminal law they think is correct, it is not necessarily true from an Islamic point of view, such as one example of the prison at Guantanamo which is full of human rights violations that have no basis for trampling or even killing someone by being tortured first (Khairul Fahmi). 
The Western version of human rights is that rights are inherent in humans because of their dignity, and not because of gifts from the state or society. These rights contain aspects of a person's life that should not be violated because he is a human being. Protection of human rights is one of the characteristics of the rule of law. Those who are concerned about human rights are of the view that the authority to revoke the right to life can be classified as a serious violation of human rights (gross violation of human rights) for depriving one of the rights that cannot be deferred (Eggi Sudjana).

These differences occur due to differences in beliefs and religions and are difficult to harmonize. However, as a Muslim, it can be measured which position is stronger as a product of God or humans, this is also inseparable from the religious beliefs adopted, but this can be an afterthought for humans who are Muslim.

\section{Conclusion}

The stipulation of the death penalty by stoning, i.e. being stoned to death against the perpetrators of the crime of adultery, is a punishment provision that existed before the advent of Islam. In Islamic law itself the practice of stoning has been practiced at the time of the Prophet and his companions. While the legal arguments in the implementation of the punishment are based on the hadith (sunnah) of the Prophet Muhammad, not on the arguments of the verses of the Qur'an. However, Muslims believe that the two sources (alquran and hadith) are the main sources in the application of a law in Islam.

In subsequent developments, the application of the death penalty by stoning for adulterers who have been categorized as muhshan (already married) has caused debate and conflict among Islamic jurists (fuqaha). This is due to different understandings and points of view regarding the position of the proposition in determining the law.

On the other hand, there is no reference that states the type of punishment that definitely violates human rights or does not violate human rights, but what is highlighted here is stoning (death). Whether the death penalty violates human rights or not, this becomes a controversy between one party and another with different perspectives. The concept of human rights in the Islamic view is different from the concept of human rights in the perspective of western countries. The conflict is especially in the matter of criminal law. Criminal law in Islam (hudud) comes from God, in which it aims to protect human rights (Ahkamaul Khamsah: protect religion, soul, mind, property, lineage/honor), which according to the Western perspective is contrary to the human rights they profess.

These differences occur due to differences in beliefs and religions and are difficult to harmonize. However, as a Muslim, it can be measured which position is stronger as a product of God or humans, this is also inseparable from the religious beliefs adopted, but this can be an afterthought for humans who are Muslim. 


\section{References}

Ali Ahmat Al-Jarjawi. Hikmah at-Tasyri' wa Falsafatuhu. Terj. Faisal Saleh. Indahnya Syari'at Islam. (Jakarta: Gema Insani. 2006).

Abd al-Al-Qadir Audah. At-Tasyri' al-Jinaiy al-Islamy. Jilid II.(Bairut: Dar al-Kitab al-Arabi,tt). Departemen Agama RI. Al-Qura'n dan Terjemahannya. (Bandung: Diponegoro. 2004).

Eggi Sudjana. HAM dalam Perspektif Islam. (Jakarta: Nuansa Madani. 2002).

Hasanuddin Yusuf. Syari'at Islam di Aceh. (Banda Aceh: Adnin Foundation. 2008).

Hasbullah, Muntasir, Saiful Bahri, Riska Zahara, Zulfia, Messages Communication in the AlQur'an (Study of Messages in the Al-Qur'an for Believers), Budapest International Research and Critics Institute-Journal (BIRCI-Journal): Volume 2 No. 4, November 2019. (http://www.bircu-journal.com/index.php/birci/article/view/569)

Ibnu Qasim al-Ghazhy. Syarah 'ala al-Fathu al-Qarib (Singapura, tt)

Ibrahim al-Bajuri. Hasyiyah al-Bajuri. (Singapura, tt).

Jalaluddin al-Mahally. Syarah 'ala Minhaj ath-Thalibin (Singapura, tt).

Khairul Fahmi, dkk. Hukum Rajam. (Banda Aceh: AJRC. 2009).

Maktabah Syamilah. Shaih Bukhari dan Shahih Muslim. 